\title{
Diversity and performance of eight new promising potato (Solanum tuberosum) genotypes in Garut District, West Java, Indonesia
}

\author{
AWANG MAHARIJAYA ${ }^{1,2, \boldsymbol{v}}$, MUHAMAD SYUKUR ${ }^{1,2}$, LINDA NUR SALMA $^{1}$, ULVI LEVIA SANUBARY ${ }^{1}$ \\ ${ }^{1}$ Departement of Agronomy and Horticulture, Faculty of Agriculture, Institut Pertanian Bogor. Jl. Meranti, Campus of IPB Dramaga, Bogor 16680, West \\ Java, Indonesia. Tel./Fax. +62-251-8629353, `email: awangmaharijaya @apps.ipb.ac.id \\ ${ }^{2}$ Center for Horticulture Tropical Studies, Institut Pertanian Bogor. Jl. Raya Pajajaran, Campus of IPB Baranangsiang, Bogor 16141, West Java, \\ Indonesia
}

Manuscript received: 20 February 2021. Revision accepted: 25 April 2021.

\begin{abstract}
Maharijaya A, Syukur M, Salma LN, Sanubary UL. 2021. Diversity and performance of eight new promising potato (Solanum tuberosum L.) genotypes in Garut District, West Java, Indonesia. Biodiversitas 22: 2848-2858. Potato (Solanum tuberosum L.) is one of the main crops in the world. Potato consumption in Indonesia continues to increase, but the supply of potatoes cannot be fully met by domestic production. The low productivity of potatoes is due to the low quality. Efforts to increase potato production are by developing new varieties with higher yields. This study aimed to obtain information about the diversity and performance of eight IPB new potato genotypes in Garut District, West Java. The study used a randomized complete block design with a one-factor genotype and four replications. The characters observed included 46 characters consisting of 27 quantitative characters and 19 qualitative characters. The genotypes that was used as materials are PKHT-2019-010, PKHT-2019-011, PKHT-2019-012, PKHT-2019-013, PKHT-2019-014, PKHT-2019-015, PKHT-2019-016, PKHT-2019-017 and two varieties Medians and Intas as control. The result showed that the potato genotypes have a diversity of leaves, stems, flowers, and tubers. PKHT-2019-010, PKHT-2019-010, PKHT-2019-015, and PKHT-2019017 have higher productivity than Medians and Intan as control. PKHT-2019-012 productivity was not significantly different from Intan as control. The genotypes that had a higher or were the same productivity as the control varieties might be the expected genotypes that can be developed as new varieties. The genotypes expected to be developed are PKHT-2019-015, PKHT-2019-010, PKHT-2019-017, and PKHT-2019-012.
\end{abstract}

Keywords: genotype, Garut, performance, productivity, yield test

\section{INTRODUCTION}

Potato (Solanum tuberosum L.) is a tuber vegetable among the fourth largest foodstuffs for the world people after rice, wheat, and maize (Saputro et al. 2019). The need for food, especially potatoes, continues to increase along with the increase in population, community education level, income level, and people's preference for potatoes. Besides being used as vegetables, potatoes can be used as raw material for food processing industries such as French fries and potato chips (Samadi 2007). Rice consumption decreased from $2009-2011$ by $1.4 \%$ due to changes in consumption patterns, resulting in increased consumption of potatoes (Hasibuan et al. 2017). Total consumption of potatoes for households from 2015-2016 increased up to $9.1 \%$ from $2.29 \mathrm{~kg} \mathrm{capita}^{-1}$ year $^{-1}$ to $2.50 \mathrm{~kg}_{\text {capita }}{ }^{-1}$ year $^{-1}$ (Pusdatin 2018). The number of potato imports in 2017 increased by $13.5 \%$ from the previous year to 106,230 tons (Kementan 2017). Therefore, potato production needs to be increased both in quality and quantity.

Public interest in potato processed products has resulted in increased national demand for potatoes. Domestic production cannot yet fulfill the supply of potatoes. The national potato production in 2019 reached 1.31 million tons (BPS 2020). Potato imports in Indonesia increased, dominated by processed potatoes such as fresh potatoes for potato chip fries, preserved potatoes, and potato starch. The number of imported potatoes until April 2018 reached 33 thousand tons (Pusdatin 2018). Since 2020, Indonesia has stopped importing potatoes. Potato productivity in Indonesia is still low compared to Europe, which reaches 40 tons $\mathrm{ha}^{-1}$. National potato productivity decreased in 2019, reaching 19.27 tons $\mathrm{ha}^{-1}$ (BPS 2020). The low productivity of potatoes is caused by some farmers' use of quality potato seeds, the development of pathogens and the accumulation of pests in the seed tubers, geographic constraints, and inadequate cultivation techniques (Thomas-Sharma et al 2016; Hasibuan et al. 2017).

Efforts to increase potato production can be made by developing new high-yielding varieties. Efforts to develop superior seeds through assembling high-yielding varieties have been carried out, such as a series of breeding activities carried out to select superior potato genotypes (Purwito et al. 2017). According to Wattimena (2000), the criteria for potatoes that are expected to become superior varieties in Indonesia are to have a short harvest life, high yield, high dry matter content, good tuber shape, and resistance to major potato diseases. The varieties are commonly cultivated in Indonesia are Atlantic and Granola. However, Atlantic is not resistant to virus attacks. One way to obtain superior varieties is to carry out plant breeding activities by characterization and exploitation of near commercial types of potato since the use of wild species is relatively avoided caused by some general constraints such as hybrid sterility 
and low crossability, retention of undesirable agronomic traits (Maharijaya and Vosman 2015).

Center for Tropical Horticulture Studies (PKHT) and the Department of Agronomy and Horticulture, Bogor Agricultural University (IPB), has made various efforts in potato plant breeding by creating new genotypes that are predicted to have better productivity than existing potato varieties including for resistance to major diseases affecting potato crops. Maharijaya (2007) has made a cross between cv. Atlantic and Granola and gained some promising genotypes through the single seeds descent method. Some potential high yielding potato of IPB genotypes have been identified and characterized (Maharijaya et al. 2008; Zulkarnain et al. 2017; Haqq 2020), including their suitability as processed potato (Maharijaya et al. 2020), their adaptation to medium altitude condition (Purwito et al. 2017) and their adaptation to drought stress (Laisina et al. 2021).

Before a genotype is released into a variety, it is necessary to test adaptation in various locations. The test aims to determine the stability of the yield and adaptability of a genotype to its growing environment. Kuswanto (2008) stated that the yield test is one of the plant breeding activities carried out before releasing varieties. This study aimed to obtain information about the diversity and performance of eight IPB new potato genotypes in Garut District, West Java, Indonesia.

\section{MATERIALS AND METHODS}

\section{Study area and materials}

The research was conducted from January to April 2020 at the Margamulya Village, Cikajang Sub-district, Garut District, West Java, Indonesia. Based on BMKG (2020) data, the rainfall that occurred during this study in January was $207.6 \mathrm{~mm}$ per month, February $336.6 \mathrm{~mm}$ per month, March $290.8 \mathrm{~mm}$ per month, and April $228.2 \mathrm{~mm}$ per month. The humidity that occurred during this study in January was $81.3 \%$, February $83.7 \%$, March $75.9 \%$, and April $82.1 \%$. The second-generation (G2) tubers that have broken dormancy (Table 1) used the plant material. The condition of the seeds before used in this study is shown in Table 2. The ideal seeds for planting are 2-6 months of dormancy, have budded $2 \mathrm{~cm}$, weight $30-50 \mathrm{~g}$, have a diameter of $3.5-4.5 \mathrm{~cm}$, and are free from pests and diseases (Indawati 2012). The ideal potato weights are PKHT-2019-015 and PKHT-2019-017. The ideal diameter of the tuber seed is PKHT-2019-015 because it has a diameter of $5.16 \mathrm{~cm}$. The bud lengths of the tubers tested were mostly less than $2 \mathrm{~cm}$. The number of buds per potato genotype ranged from 1.1-4.1 (Table 2). Almost all IPB potato seeds were attacked by fleas, it was probably the warehouse conditions that were too humid. Tuber damage during storage is influenced by several factors such as tubers stored by stacking, air circulation, and storage temperature. Accumulated tubers will result in obstructed air circulation.

Table 1. The material plant used in the test.

\begin{tabular}{lll}
\hline Genotype/variety & Source & \multicolumn{1}{c}{ Status } \\
\hline PKHT-2019-010 & PKHT IPB & Genotype test \\
PKHT-2019-011 & PKHT IPB & Genotype test \\
PKHT-2019-012 & PKHT IPB & Genotype test \\
PKHT-2019-013 & PKHT IPB & Genotype test \\
PKHT-2019-014 & PKHT IPB & Genotype test \\
PKHT-2019-015 & PKHT IPB & Genotype test \\
PKHT-2019-016 & PKHT IPB & Genotype test \\
PKHT-2019-017 & PKHT IPB & Genotype test \\
Medians & Indonesian Vegetable & Control \\
& Crop Research Center & \\
Intan & Dept of Food Crops and & Control \\
& Horticulture Garut & \\
\hline
\end{tabular}

Table 2. Seed characteristics for each IPB potato genotype

\begin{tabular}{lcccc}
\hline Genotype/variety & Seed weight $(\mathbf{g})$ & Seed diameter $(\mathbf{c m})$ & Bud length $(\mathbf{c m})$ & Number of buds \\
\hline PKHT-2019-010 & $16.158 \mathrm{de}$ & $2.66 \mathrm{~b}$ & $0.71 \mathrm{~cd}$ & $4.1 \mathrm{a}$ \\
PKHT-2019-011 & $21.815 \mathrm{c}$ & $2.99 \mathrm{~b}$ & $0.60 \mathrm{~d}$ & $2.8 \mathrm{~cd}$ \\
PKHT-2019-012 & $29.908 \mathrm{~b}$ & $2.78 \mathrm{~b}$ & $1.22 \mathrm{~b}$ & $2.6 \mathrm{~d}$ \\
PKHT-2019-013 & $13.115 \mathrm{ef}$ & $2.48 \mathrm{~b}$ & $0.87 \mathrm{c}$ & $1.9 \mathrm{e}$ \\
PKHT-2019-014 & $21.045 \mathrm{~cd}$ & $2.75 \mathrm{~b}$ & - & $3.1 \mathrm{f}$ \\
PKHT-2019-015 & $42.863 \mathrm{a}$ & $5.16 \mathrm{a}$ & - & $1.5 \mathrm{ef}$ \\
PKHT-2019-016 & $18.888 \mathrm{~cd}$ & $2.99 \mathrm{~b}$ & $0.77 \mathrm{~cd}$ & $3.5 \mathrm{~b}$ \\
PKHT-2019-017 & $30.303 \mathrm{~b}$ & $2.92 \mathrm{~b}$ & $1.09 \mathrm{~b}$ & $1.3 \mathrm{f}$ \\
Intan & $8,490 \mathrm{fg}$ & $2.67 \mathrm{~b}$ & $0.61 \mathrm{~d}$ & $1.5 \mathrm{f}$ \\
Medians & $8.075 \mathrm{~g}$ & $2.09 \mathrm{~b}$ & $1.54 \mathrm{a}$ & \\
\hline
\end{tabular}

Note: The numbers followed by the same letter in the same column show the results are not significantly different in the Duncan test at the level of $\alpha=5 \%,-=$ no bud length 


\section{Procedures}

This study used a single-factor randomized complete group design, in which the genotype as a factor. We used eight IPB genotypes with two controls, with four replicates. Thus, there were 40 experimental units, with each experimental unit consisting of 24 plants. Each genotype was planted on mounds $3.5 \mathrm{~m}$ long, $1 \mathrm{~m}$ wide, $30 \mathrm{~cm}$ high, and $40 \mathrm{~cm}$ space between mounds. Land measuring 218.4 $\mathrm{m}^{2}$ formed 40 mounds; each mound consists of 24 plants. Planting is adjusted to cultivation techniques in general farmers in Garut do and refers to research that has been carried out previously by Haqq (2020) and modifying the dosage of fertilizers from the research of Barunawati and Zakariyah (2016). Planting was carried out at a spacing of $50 \times 28 \mathrm{~cm}$. Potato seeds are planted at a depth of between 7-10 $\mathrm{cm}$. Giving manure at a dose of 10 ton $^{-{ }^{-1}} 14$ days before planting, $400 \mathrm{~kg} \mathrm{ha}^{-1}$ NPK (15-15-15), $320 \mathrm{~kg} \mathrm{ha}^{-1}$ $\mathrm{ZA}$, and $320 \mathrm{~kg} \mathrm{ha}^{-1}$ TSP at 26 days after planting (DAP).

Maintenance includes weeding, propping, pest, and disease control were performed according to the Handbook for Potato Production provided by the Directorate General of Horticulture, Ministry of Agriculture (2015). Weeding is done manually every week until the plants are 60 DAP. Propping the plants to the stake is carried out when the plants reach 38 days after planting. Pest and disease control is carried out at 21 to 63 DAP intensively using chemicals. Harvesting is carried out when the plants have reached harvest age (90-120 DAP) which is indicated by the leaves and stems of the plants that have turned yellow and have dried more than $80-85 \%$ of the population. The harvested tubers were separated based on the genotype of each sample plant, then cleaned and collected in one container to measure the post-harvest yield.

\section{Observation}

The vegetative quantitative characters observed were the percentage of the live plant (comparing the number of living plants to the number of plants planted), plant height (measured from the soil surface to the point of growing plants), stem diameter (measuring on the main stem with a height of $10 \mathrm{~cm}$ from the ground surface), number of branches (counting the number of branches emerging from the main stem), number of leaves (counting the number of fully grown compound leaves), leaf size (length and width of terminal and lateral leaves, and length of leaf outline). The generative quantitative characters observed were flowering time (calculated after $50 \%$ of the flowering population), harvest time (80-85\% of the plants had fallen, the leaves and stems were dry).

Qualitative observations refer to the description of the UPOV (International Union for the Protection of New Varieties of Plants) (2004). The qualitative variables observed were leaf morphology including leaf color, leaf texture, primary leaf shape and leaf shape, shoot color, leaf hair, leaf width, and leaf arrangement. Stem morphology includes the color of the stem and the shape of the crosssection of the stem. Flower morphology includes the shape of the flower crown, the color of the flower crown. Potato tuber morphology includes tuber skin color and tuber flesh color using the Royal Horticultural Society Color Chart
(RHSCC).

Post-harvest quantitative characters observed were unit weight per tuber (calculated from tuber unit weight per sample plant), number of tubers per plant, tuber weight per plant (tuber weight divided by the number of plants in each experimental unit), weight per ha (tuber weight conversion. per plant multiplied by the number of population), tuber length (tuber diameter on the $\mathrm{X}$-axis), tuber width (tuber diameter on the Y-axis), number of tuber eyes per tuber, and tuber shape (ratio of length and width of tubers multiplied by 100) in tubers that have the shape and dominant size. The tuber shape criteria are round (100$109)$, short oval (110-129), oval (130-149), long oval (150169), long (170-199), and very long (200). The grading classification of potato tubers is based on the weight of potato tubers through SNI-01-3175-1992 standards which consist of very large (> $301 \mathrm{~g})$, large (101-300 g), medium $(51-100 \mathrm{~g})$, and small $(<50 \mathrm{~g})$.

\section{Data analysis}

The quantitative data obtained in this study were analyzed using analysis of variance ( $F$ test). The $F$ test is performed to determine whether there are differences in the effect of treatments. If the $\mathrm{F}$ test shows a significant effect at the 5\% level, further testing is carried out using the Duncan multiple-range test (Duncan 1955). The entire data analysis process used Microsoft Office Excel 2013 software and Statistical Analysis System (SAS) 9.0.

\section{RESULTS AND DISCUSSION}

\section{General condition}

The ideal rainfall required for potato plants ranges from 160-250 mm per month. The humidity for growing potatoes is $80-90 \%$. The ideal growth requirements for potato plants compiled by BPTP (2015) are an altitude of more than $1,000 \mathrm{~m}$ asl., a temperature between $15-20^{\circ} \mathrm{C}$, and rainfall between 1,500-5,000 $\mathrm{mm}$ per year. Thus, in this study, the potato plant had an environment as a less than ideal growing condition because high rainfall would cause the land to become humid, so that the development of pests and diseases increased.

The diseases found in this study were leaf blight, bacterial wilt, fusarium wilt, and PVX virus. According to Sastrahidayat (2011), leaf blight is caused by the fungus Phytophthora infestans, which is characterized by symptoms of the leaves and stems turning blackish-brown due to rot. Gold et al. (2020) reported that the pathogen could have triggered the plant to take up more water at the expense of other activities. The highest blight attack occurred at the age of the plant 48 DAP. Leaf blight almost attacked the plants tested; the worst attack occurred in PKHT-2019-014. According to Zulkarnain et al. (2017), the worst attack caused by the Ralstonia solanacearum bacteria that causes bacterial wilt is tuber rot. This disease causes wilting of the young leaves and then spreads to the stem. The highest bacterial wilt attack occurred in the PKHT-2019-011 genotype at the age of 44 DAP. 
The PKHT-2019-012 and PKHT-2019-016 genotypes may be indicated by the PVX virus, seen from the physical performance of the potato plant leaves, which are experiencing shrinkage, besides experiencing slow growth. According to Sastrahidayat (2011), the characteristics of potato plants affected by the PVX virus are that the leaves experience necrosis (yellowish-green color), systematic wrinkling of all leaves, and the performance of dwarf plants. Fusarium wilt disease is caused by the fungus Fusarium oxysporum, causing brown and slimy stem and root tissue. Fusarium wilt disease was found in the PKHT2019-011 and PKHT-2019-013 genotypes. Disease control is carried out by removing the affected plants so that transmission does not occur and chemical administration by spraying pesticides regularly.

The pest that attacked the potato during the study was Gryllotalpa orientalis. Potato plants attacked by $G$. orientalis may during the tuber enlargement stage until the tubers ripen. G. orientalis that are in the soil often attack potato tubers, causing tubers to be hollow, almost all potato genotypes are affected by the $G$. orientalis, but the worst attack occurred in the PKHT-2019-013 genotype. Besides, some tubers are perforated by rats (Rattus argentiventer).

\section{Diversity of quantitative and qualitative characters of the potato genotypes}

the analysis results showed the genotype treatment that was carried out had a very significant effect on all variables at the 5\% level. Almost all of the repetition treatment or block effect had no significant effect, except that the observed variables were the percentage of living plants and the number of branches which had a very significant effect, while the variables of stem diameter had a significant effect. The results of the recapitulation of variance and the percentage coefficient of variance are presented in detail in Table 3.

\section{Quantitative characters}

\section{Percentage of live plants}

The percentage of live plants indicates that the plants are well adapted to the environment. The percentage of live plants at 28 DAP from the 10 genotypes tested ranged from 30.20-100\% (Table 4). The PKHT-2019-011 genotype has a survival rate of $95,83 \%$. Plants that have a high percentage of life are plants that can adapt well so that they have good vigor. The PKHT-2019-014 and PKHT-2019015 genotypes have a low survival rate. PKHT-2019-014 shows slow growth compared to other genotypes, most likely because the genotype does not suit the agro-climatic conditions of Garut District, besides the condition of the seeds which have few buds so that vegetative growth is slow.

The genotype with low growth power may be caused by rotting tubers in the soil so that growth does not occur. The rotten tuber seeds are thought to be attacked by bacterial wilt. Suboptimal environmental conditions, high rainfall during the study resulted in increased disease in potato plants. According to Maharijaya (2007), generally, bacterial wilt disease can be spread through infected soil, infected tuber seeds, roots of other plants in the soil, irrigation water, rainwater splashes, and tools used during cultivation. Plants infected with severe bacterial wilt are removed from these plants to prevent transmission to other plants.

Table 3. Recapitulation of variance on research observation variables

\begin{tabular}{lccc}
\hline Variable & $\begin{array}{c}\text { Genotype } \\
\text { influence }\end{array}$ & $\begin{array}{c}\text { The group } \\
\text { effect }\end{array}$ & $\begin{array}{c}\text { Coefficient } \\
\text { of variance } \\
(\%)\end{array}$ \\
\hline Seed weight & $* *$ & $\mathrm{Sn}$ & 15.37 \\
Seed diameter & $* *$ & $\mathrm{Sn}$ & 23.10 \\
Bud length & $* *$ & $\mathrm{Sn}$ & 15.38 \\
Number of buds & $* *$ & $\mathrm{Sn}$ & 11.91 \\
Percentage of live plants & $* *$ & $* *$ & 2.60 \\
Plant height & $* *$ & $\mathrm{Sn}$ & 13.55 \\
Stem diameter & $* *$ & $*$ & 11.93 \\
Number of branches & $* *$ & Sn & 3.83 \\
Number of leaves & $* *$ & $\mathrm{Sn}$ & 7.14 \\
Weight per unit of tubers & $* *$ & $\mathrm{Sn}$ & 26.37 \\
Number of tubers per plant & $* *$ & $\mathrm{Sn}$ & 27.08 \\
Weight per plant & $* *$ & $\mathrm{Sn}$ & 25.84 \\
Weight per ha & $* *$ & $\mathrm{Sn}$ & 9.93 \\
Tuber length & $* *$ & $\mathrm{Sn}$ & 8.42 \\
Tuber diameter & $* *$ & $\mathrm{Sn}$ & 13.28 \\
Number of sprouts & $* *$ & $\mathrm{Sn}$ & 10.20 \\
Terminal leaf length & $* *$ & $\mathrm{Sn}$ & 8.93 \\
Terminal leaf width & $* *$ & $\mathrm{Sn}$ & 12.93 \\
Lateral leaf length & $* *$ & $\mathrm{Sn}$ & 13.47 \\
Lateral leaf width & $* *$ & $\mathrm{Sn}$ & 18.24 \\
Leaf outline length &
\end{tabular}

Note: $\mathrm{sn}=$ no significant effect, $*=$ significant effect at the level $\alpha=5 \%, * *=$ very significant effect at the level $\alpha=5 \%$.

Table 4. Characteristics of potato plant growth and characteristics of harvest time for each IPB potato genotype

\begin{tabular}{|c|c|c|c|c|c|c|c|}
\hline Genotype & $\begin{array}{c}\text { The live } \\
\text { plant }(\%)\end{array}$ & $\begin{array}{c}\text { Plant height } \\
(\mathrm{cm})\end{array}$ & $\begin{array}{c}\text { Stem diameter } \\
(\mathrm{mm})\end{array}$ & $\begin{array}{c}\text { Number of } \\
\text { branches }\end{array}$ & $\begin{array}{l}\text { Number of } \\
\text { leaves }\end{array}$ & $\begin{array}{l}\text { Harvest time } \\
\text { (DAP) }\end{array}$ & $\begin{array}{c}\text { Harvest age } \\
\text { class }\end{array}$ \\
\hline PKHT-2019-010 & $100.00 \mathrm{a}$ & $49.83 \mathrm{a}$ & $8.72 b c$ & $15.2 \mathrm{a}$ & $90.6 \mathrm{a}$ & $94.00 \mathrm{~b}$ & Quickly \\
\hline РКНТ-2019-011 & $95.83 b$ & $37.20 \mathrm{~b}$ & $9.93 b$ & $13.3 \mathrm{~b}$ & $80.5 b$ & $69.25 \mathrm{e}$ & Quickly \\
\hline РКНТ-2019-012 & $100.00 \mathrm{a}$ & $38.96 b$ & $7.95 \mathrm{~cd}$ & $15.1 \mathrm{a}$ & $92.7 \mathrm{a}$ & $92.00 \mathrm{c}$ & Quickly \\
\hline PKHT-2019-013 & $96.88 \mathrm{ab}$ & $31.99 b c$ & $5.99 \mathrm{e}$ & $14.9 \mathrm{a}$ & $89.6 \mathrm{a}$ & $90.00 \mathrm{~d}$ & Quickly \\
\hline PКHT-2019-014 & $34.78 \mathrm{c}$ & $27.91 \mathrm{~cd}$ & $6.05 \mathrm{e}$ & $13.1 \mathrm{bc}$ & $72.5 b$ & $90.00 \mathrm{~d}$ & Quickly \\
\hline PKHT-2019-015 & $30.20 \mathrm{~d}$ & $39.70 b$ & $11.80 \mathrm{a}$ & $15.0 \mathrm{a}$ & $93.5 \mathrm{a}$ & $97.00 \mathrm{a}$ & Quickly \\
\hline РКНТ-2019-016 & $100.00 \mathrm{a}$ & $21.98 \mathrm{~d}$ & $6.22 \mathrm{e}$ & $12.4 \mathrm{c}$ & $72.7 b$ & $97.00 \mathrm{a}$ & Quickly \\
\hline РКНТ-2019-017 & $100.00 \mathrm{a}$ & $51.93 \mathrm{a}$ & $8.98 b c$ & $14.7 \mathrm{a}$ & $90.6 \mathrm{a}$ & $93.00 \mathrm{bc}$ & Quickly \\
\hline Intan & $100.00 \mathrm{a}$ & $24.65 \mathrm{~cd}$ & $6.58 \mathrm{de}$ & $13.0 \mathrm{bc}$ & $78.5 b$ & $98.00 \mathrm{a}$ & Quickly \\
\hline Medians & $100.00 \mathrm{a}$ & $38.69 \mathrm{~b}$ & $9.96 \mathrm{~b}$ & $13.2 \mathrm{bc}$ & $79.5 b$ & $97.00 \mathrm{a}$ & Quickly \\
\hline
\end{tabular}

Note: The numbers followed by the same letter in the same column show the results are not significantly different in the Duncan test at the level of $\alpha=5 \%$. 
Table 5. Leaf size characteristics of the IPB potato genotype at 42 DAP

\begin{tabular}{lcccc}
\hline Genotype & $\begin{array}{c}\text { Leaf length } \\
\text { terminal }(\mathbf{c m})\end{array}$ & $\begin{array}{c}\text { Leaf width } \\
\text { terminal }(\mathbf{c m})\end{array}$ & $\begin{array}{c}\text { Leaf length lateral } \\
(\mathbf{c m})\end{array}$ & $\begin{array}{c}\text { Leaf width } \\
\text { lateral }(\mathbf{c m})\end{array}$ \\
\hline PKHT-2019-010 & $7.33 \mathrm{bc}$ & $5.30 \mathrm{abc}$ & $6.00 \mathrm{cde}$ & $4.08 \mathrm{abc}$ \\
PKHT-2019-011 & $8.13 \mathrm{ab}$ & $5.80 \mathrm{a}$ & $7.60 \mathrm{ab}$ & $4.38 \mathrm{ab}$ \\
PKHT-2019-012 & $8.18 \mathrm{ab}$ & $5.53 \mathrm{ab}$ & $7.00 \mathrm{abcd}$ & $4.55 \mathrm{a}$ \\
PKHT-2019-013 & $6.80 \mathrm{c}$ & $3.98 \mathrm{e}$ & $5.38 \mathrm{e}$ & $2.70 \mathrm{~d}$ \\
PKHT-2019-014 & $6.70 \mathrm{c}$ & $4.65 \mathrm{cde}$ & $5.75 \mathrm{de}$ & $3.58 \mathrm{bc}$ \\
PKHT-2019-015 & $7.73 \mathrm{bc}$ & $5.45 \mathrm{ab}$ & $7.25 \mathrm{abc}$ & $4.60 \mathrm{a}$ \\
PKHT-2019-016 & $7.18 \mathrm{bc}$ & $4.30 \mathrm{de}$ & $6.23 \mathrm{bcde}$ & $3.43 \mathrm{~cd}$ \\
PKHT-2019-017 & $7.68 \mathrm{bc}$ & $5.63 \mathrm{ab}$ & $6.70 \mathrm{abcde}$ & $4.18 \mathrm{abc}$ \\
Intan & $7.35 \mathrm{bc}$ & $4.90 \mathrm{bcd}$ & $6.70 \mathrm{abcde}$ & $23.08 \mathrm{a}$ \\
Medians & $9.25 \mathrm{a}$ & $5.80 \mathrm{a}$ & $7.78 \mathrm{a}$ & $4.03 \mathrm{abc}$ \\
\hline
\end{tabular}

Note: The numbers followed by the same letter in the same column show the results are not significantly different in the Duncan test at the level of $\alpha=5 \%$.

\section{Plant height}

The research data were taken when the plants had grown when the plants started flowering at 46-56 DAP. This study using 42 DAP data. The plant height of each potato genotype ranged from $21.98-49.83 \mathrm{~cm}$ (Table 4). The genotypes with the highest yield among other genotypes and comparison varieties were PKHT-2019-017 and PKHT-2019-010. The PKHT-2019-016 genotype had the lowest plant height and was not significantly different from PKHT-2019-014 and Intan. Based on the height, the potato plant can be classified into five levels in the UPOV (2004) character, namely very short $(<44.0 \mathrm{~cm})$, short $(44.1-49.9 \mathrm{~cm})$, medium $(50.0-59.9 \mathrm{~cm})$, and very high $(>$ $60.0 \mathrm{~cm})$. Based on the observations, the plants tested were classified as very short and short.

\section{Stem diameter}

Stem diameter has an important role in supporting the uprightness of plants so that plants do not fall easily and are expected to have a large stem diameter (Hidayat et al. 2018). The PKHT-2019-015 genotype had the largest stem diameter, $11.80 \mathrm{~mm}$, compared to other genotypes and comparison varieties Intan and Medians. PKHT-2019-013 has the smallest stem diameter, not significantly different from PKHT-2019-014, PKHT-2019-016, and Intan. Ebrahim et al. (2018) stated that the size of the large seed tubers affects the stem diameter. This is in line with our result the PKHT-2019-015 has the largest seed diameter
(Table 2). The stem diameter of each genotype tested ranged from 5.99-11.80 mm. Based on field observations, PKHT-2019-013 experienced a lot of collapsing because it had a relatively small diameter, so that several reminders were made at stake.

\section{Number of branches and leaves}

The number of branches varies between genotypes, and the more the number of branches can increase the number of leaves (Table 4). The PKHT-2019-010 genotype has the largest number of branches, not statistically significant from PKHT-2019-012, PKHT-2019-013, PKHT-2019-015, and PKHT-2019-017. The PKHT-2019-016 genotype had the lowest number of branches of 12.4, not significantly different from PKHT-2019-014 and two control varieties. Based on the data tested, the number of branches obtained ranged from 12.4-15.2. Different adaptations of each genotype cause the difference in the number of branches and leaves.

Leaves are the main photosynthetic organ in leaves because photosynthesis occurs in them. The expected criteria for potato leaves are large and large (Hidayat 2014). The PKHT-2019-015 genotype had the highest number of leaves compared to the comparison varieties of Intan and Medians, not significantly different from PKHT2019-010, PKHT-2019-012, PKHT-2019-013, and PKHT2019-017. The number of leaves per potato genotype obtained ranged from 72.5 to 93.5 .

Table 6. Leaf size characteristics of the IPB potato genotype

\begin{tabular}{|c|c|c|c|c|c|c|c|c|}
\hline Genotype & Leaf color & $\begin{array}{c}\text { Leaf top } \\
\text { color } \\
\end{array}$ & $\begin{array}{c}\text { Leaf } \\
\text { texture }\end{array}$ & $\begin{array}{c}\text { Leaf } \\
\text { hair* }\end{array}$ & $\begin{array}{l}\text { Leaflet } \\
\text { width* }\end{array}$ & $\begin{array}{c}\text { Leaf } \\
\text { arrangement* }\end{array}$ & $\begin{array}{c}\text { Shape primary } \\
\text { leaf* }\end{array}$ & $\begin{array}{c}\text { Shape } \\
\text { secondary leaf* } \\
\end{array}$ \\
\hline PKHT-2019-010 & Dark green & Light green & Flat & Lots & Moderate & Intermediate & Ovate & Oval \\
\hline PKHT-2019-011 & Dark green & Green & Flat & a little & Moderate & Intermediate & Ovate & Round \\
\hline РКНT-2019-012 & Dark green & Light green & Wrinkles & a little & Moderate & Intermediate & Ovate & Round \\
\hline PKHT-2019-013 & Dark green & Green & Flat & a little & Narrow & Open & Elliptical & Oval \\
\hline PKHT-2019-014 & Dark green & Light green & Rather wavy & Moderate & Wide & Closed & Ovate & Oval \\
\hline PKHT-2019-015 & Dark green & Light green & Rather flat & Lots & Wide & Closed & Ovate & Round \\
\hline PKHT-2019-016 & Dark green & Green & Rather wavy & Moderate & Narrow & Open & Elliptical & Oval \\
\hline PKHT-2019-017 & Dark green & Light green & Flat & Moderate & Moderate & Intermediate & Ovate & Round \\
\hline Intan & Dark green & Green & Rather wavy & Moderate & Moderate & Open & Ovate & Oval \\
\hline Medians & Green & Light green & Wavy & a little & Wide & Open & Ovate & Oval \\
\hline
\end{tabular}

Note: *=based on UPOV (2004) 
The terminal leaf length of each genotype ranged from $6.70-9.25 \mathrm{~cm}$ (Table 5). The medians have the largest terminal leaf size of $9.25 \mathrm{~cm}$. The tested leaf width ranges from $3.98-5.80 \mathrm{~cm}$. The tested lateral leaf lengths ranged from $5.38-7.78 \mathrm{~cm}$, and lateral leaf widths ranged from 2.70-4.60 cm. According to Haqq (2020), the length and width of the terminal leaves will be greater than the length and width of the lateral leaves. The highest leaf outline lengths in Median, Intan, PKHT-2019-015, and PKHT2019-011, are not significantly different from PKHT-2019010, PKHT-2019-012, PKHT-2019-016, and PKHT-2019012 . The length of the leaf outline will affect the coverage area in which sunlight is captured.

\section{Harvesting time}

Potato crops can be harvested when $80-85 \%$ of the leaves have turned yellow and the plant has fallen. Harvesting of potatoes was carried out according to the time of harvest for each genotype. The harvest times obtained ranged from 62.25-98 DAP (Table 4). PKHT2019-011 was harvested early because many plants were attacked by bacterial wilt. The PKHT-2019-015 genotype can be predicted to last longer than the harvest time obtained because some plants are starting to be attacked by bacterial wilt and the constant rains are feared to lose production. According to Zulkarnain et al. (2017), harvesting is carried out at the early harvest time to reduce large yields due to pest and disease attacks.

Harvesting earlier will result in a decrease in the quality and quantity of tubers. Plants that are harvested earlier will cause damage to the tuber rind because the tuber rind is easily peeled off. Besides, early harvesting is that the potato tubers are small because the tuber formation process is not optimal. Based on the data tested, the potato harvest age class was classified as early maturity. The potato harvest age ranges from 80-180 DAP, depending on the variety. According to Sastrahidayat (2011), early potato varieties (90-120 DAP), medium varieties (120-150 DAP), and deep varieties (150-180 DAS). The advantage of shortlived potato crops is that they do not need a lot of maintenance costs and are profitable for farmers because they get faster yields. According to Asgar et al. (2011), potato tubers harvested at old age have a higher starch content than tubers harvested at a younger age.

\section{Qualitative characters \\ Leaf characters}

Potato leaves are compound leaves that vary in color, shape, and size depending on the variety (Figure 1). The leaf color characterization tested was generally dark green, except for the Median, which was green. The leaf texture of each genotype is generally different. PKHT-2019-010, PKHT-2019-011, PKHT-2019-013, and PKHT-2019-017 have a leaf texture average, while PKHT-2019-015 is rather flat (Table 6). PKHT-2019-012 has a wrinkled leaf texture because the PVX virus indicates some plants. The slightly wave leaf texture belongs to the PKHT-2019-014, PKHT2019-016, and Intan genotypes, while the Median has a wavy leaf texture. The primary leaf shape consists of an ovate and elliptic. PKHT-2019-013 and PKHT-2019-016 have elliptical leaves, while the rest have ovate leaves. The secondary leaf shape consists of oval and round.

Table 7. Color of the stem and cross-sectional shape of each IPB potato genotype

\begin{tabular}{lcc}
\hline Genotype & Stem color & Stem cross-sectional shape \\
\hline PKHT-2019-010 & Gray Green & Round \\
PKHT-2019-011 & Purplish Green & Angular \\
PKHT-2019-012 & Gray Green & Round \\
PKHT-2019-013 & Green & Angular \\
PKHT-2019-014 & Light green & Round \\
PKHT-2019-015 & Green & Round \\
PKHT-2019-016 & Gray Green & Elliptic \\
PKHT-2019-017 & Gray Green & Round \\
Intan & Green & Angular \\
Medians & Light green & Round \\
\hline
\end{tabular}

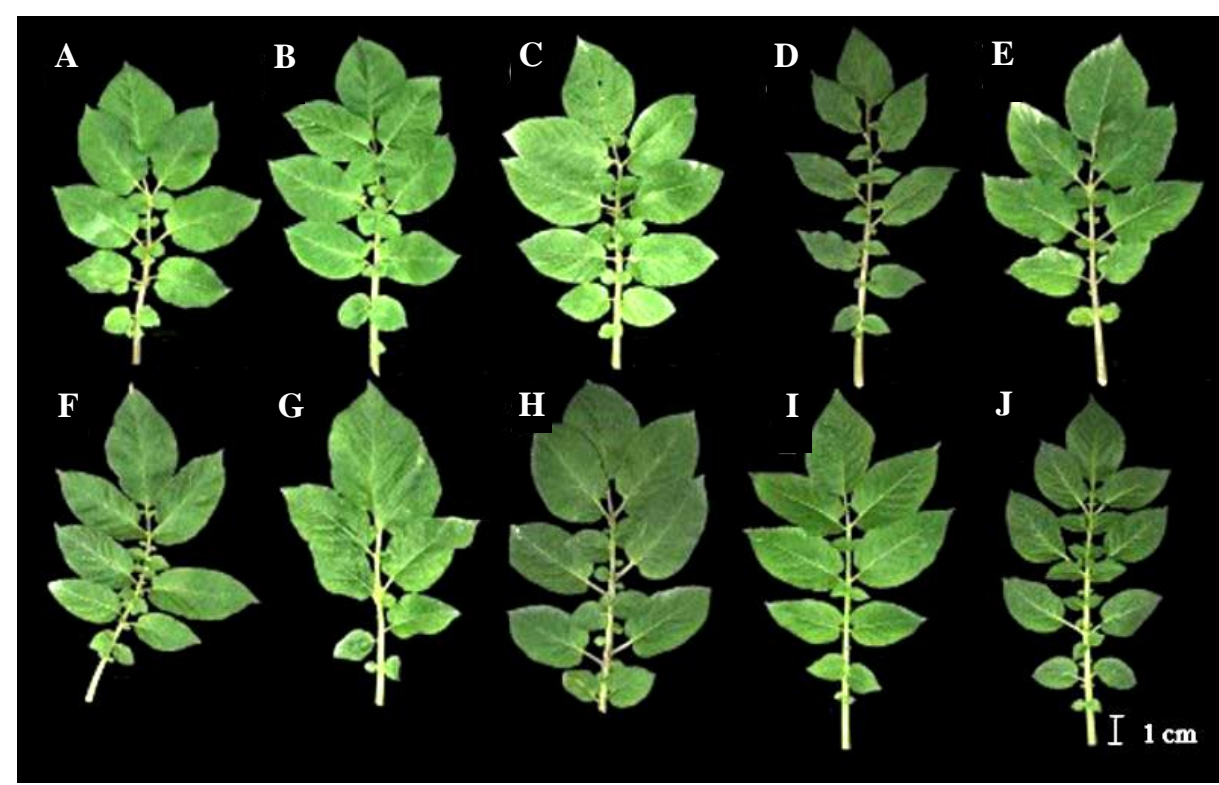

Figure 1. Appearance of the leaf and stem shape of the IPB potato genotype. Description: A. PKHT-2019-010; B. PKHT-2019-011; C. PKHT2019-012; D. PKHT-2019-013; E. PKHT-2019-014; F. PKHT-2019-015; G. PKHT-2019-016; H. PKHT-2019-017; I. Medians; J. Intan 
Table 8. Characterization of flower for each IPB potato genotype

\begin{tabular}{|c|c|c|c|c|c|}
\hline \multirow{2}{*}{ Genotype } & \multirow{2}{*}{ Flower crown shape } & \multicolumn{2}{|c|}{ Color of the flower crown } & \multirow{2}{*}{$\begin{array}{c}\text { Color of the } \\
\text { pistil head }\end{array}$} & \multirow{2}{*}{ Color of the stamen } \\
\hline & & Inside & Main & & \\
\hline PKHT-2019-010 & Pentagonal & Green & White & Dark green & Yellow \\
\hline PKHT-2019-011 & Pentagonal & Dark Purple & Purple & Dark green & Yellow \\
\hline PKHT-2019-012 & - & - & - & - & - \\
\hline PKHT-2019-013 & Semi-stellate & Green & Violet & Dark green & Yellow \\
\hline PKHT-2019-014 & - & - & - & - & - \\
\hline PKHT-2019-015 & Pentagonal & Green & Violet & Dark green & Yellow \\
\hline PKHT-2019-016 & Semi-stellate & Dark Purple & Purple & Light green & Yellow \\
\hline PKHT-2019-017 & Pentagonal & Green & White & Dark green & Yellow \\
\hline Intan & - & - & - & - & - \\
\hline Medians & Rotate & Green & Purple & Light green & Yellow \\
\hline
\end{tabular}

Note: The numbers followed by the same letter in the same column show the results are not significantly different in the Duncan test at the level of $\alpha=5 \%$, - = does not flower.

The leaf color of each genotype is divided into light green and green. The leaf hairs on the upper surface of the leaves are called trichomes, which are the plants' selfdefense tools from invading organisms. Leaf hairs are mostly owned by PKHT-2019-010 and PKHT-2019-015. There are three types of leaflets, namely narrow, medium, and wide. The genotypes that have narrow leaflets are PKHT-2019-013 and PKHT-2019-016. Genotypes PKHT2019-010, PKHT-2019-011 PKHT-2019-012, PKHT-2019017, and Intan have medium leaf width. Based on UPOV (2004), the leaf arrangement of each genotype is different, consisting of open, intermediate, and closed.

\section{Stem characters}

The color and shape of the cross-section of potato have the characteristics of each variety but generally have a green color. The gray-green color of PKHT-2019-10, PKHT-2019-012, PKHT-2019-016, and PKHT-2019-017, while PKHT-2019-011 is purplish-green (Table 7). The cross-sectional shape of the stems tested varied greatly between genotypes, consisting of round, elliptic, and angular. PKHT-2019-011, PKHT-2019-013, and Intan genotypes have an angular cross-sectional shape. PKHT2019-016 has an elliptic cross-sectional shape. The remaining genotypes have a round cross-sectional shape (Table 7).

\section{Flower characters}

The flowers on the potato plant are located on the axillary leaves. In this study, not all genotypes could produce any flower. Plantenga et al. (2019) reported that the effects of photoperiod and tuberization can cause failure of flowering. The assimilation that is not maximal causes the tubers to be unable to support flowering. Besides that, it was thought that due to suboptimal environmental conditions, high rainfall during the study. According to Upadhya et al. (1984), a potato crop will produce flowers if the altitude is suitable, the climate is cold, and the length of the sun is 14-16 hours per day. However, in this study all the environmental conditions are equal, thus the inability to produce flowers might be caused mainly by genetic factors. The genotypes that flowering are PKHT-2019-010, PKHT2019-011, PKHT-2019-013, PKHT-2019- 015, PKHT2019-016, PKHT-2019-017, and Medians (Figure 2).

Table 9. Characterization of tubers for each IPB potato genotype

\begin{tabular}{|c|c|c|c|c|c|c|}
\hline Genotype & $\begin{array}{c}\text { Tuber } \\
\text { length }(\mathrm{cm})\end{array}$ & $\begin{array}{c}\text { Tuber width } \\
(\mathrm{cm})\end{array}$ & $\begin{array}{l}\text { Number of } \\
\text { eyes tubers }\end{array}$ & $\begin{array}{l}\text { Tuber } \\
\text { shape }\end{array}$ & Color of rind tubers & Color of flesh tubers \\
\hline PKHT-2019-010 & $5.03 \mathrm{~cd}$ & $2.77 \mathrm{de}$ & $3.2 \mathrm{de}$ & Long & Yellowish Red (31B) & Light Yellow (13A) \\
\hline PKHT-2019-011 & $5.03 \mathrm{~cd}$ & $3.21 \mathrm{~cd}$ & $8.0 \mathrm{a}$ & Long oval & Dark Purple (79A) & Dark Purple (79B) \\
\hline PKHT-2019-012 & $6.50 \mathrm{a}$ & $2.65 \mathrm{e}$ & $3.5 \mathrm{cde}$ & Very long & $\operatorname{Red}(51 \mathrm{~A})$ & Light Yellow (13B) \\
\hline РКНТ-2019-013 & $3.64 \mathrm{e}$ & $2.94 \mathrm{de}$ & $2.7 \mathrm{e}$ & Short oval & Light Yellow (11A) & Light Yellow (12C) \\
\hline РКНТ-2019-014 & $4.71 \mathrm{~d}$ & $2.69 \mathrm{e}$ & $3.7 \mathrm{cde}$ & Long & Yellow (15 A) & Yellow (14A) \\
\hline РКНТ-2019-015 & $6.09 \mathrm{ab}$ & $4.82 \mathrm{a}$ & $7.5 \mathrm{a}$ & Short oval & Purple Red (42D) & Light Yellow (14C) \\
\hline РКНТ-2019-016 & $4.27 \mathrm{de}$ & $3.45 \mathrm{c}$ & $4.2 \mathrm{bc}$ & Short oval & Pink (41D) & Light Yellow (13B) \\
\hline РКНT-2019-017 & $5.66 \mathrm{bc}$ & $3.19 \mathrm{~cd}$ & $4.3 \mathrm{bc}$ & Long & Red (38 A) & Light Yellow (11B) \\
\hline Intan & $6.66 \mathrm{a}$ & $4.31 b$ & $4.9 \mathrm{~b}$ & Long oval & Brown (161 D) & Light Yellow (9D) \\
\hline Medians & $4.51 \mathrm{~d}$ & $3.47 \mathrm{c}$ & $3.7 \mathrm{~cd}$ & Short oval & Yellow (24 A) & White (11D) \\
\hline
\end{tabular}

Note: The numbers followed by the same letter in the same column show the results are not significantly different in the Duncan test at the level of $\alpha=$ 5\%. Color-based on Royal Horticulture Society Color Chart (RHSCC) 
The morphological characters of the flowers and the color of each potato genotype were different from one another. The difference in flower color is affected by the genetic factors of each genotype. Based on the researchtested, there were pentagonal, semi-stellate, and rotate flower crowns. Flowers on potato plants can be white, purple, purplish-red, and blue (Sastrahidayat 2011). Observation of flower crown color can be divided into deep and main. The color of the inner crown lies in the innermost part of the stamen. The main color of the crown is the dominant color. The PKHT-2019-011 and PKHT2019-016 genotypes have dark purple inner crown color, the rest have a green color. PKHT-2019-010 and PKHT2019-017 have white main flower crowns, the rest have purple and dark purple. The color of the pistil of each genotype generally has a light green and dark green color. The color of the stamens of each genotype has yellow color.

\section{Tuber characters}

The rind color of the tubers of each genotype varies greatly from one another (Figure 3). PKHT-2019-010, PKHT 2019-012, PKHT-2019-016, and PKHT-2019-017 have red tuber rind color. The red color found in tubers contains anthocyanins. Dhar et al. (2015) reported that Solanaceae species exhibit a variety of tuber colors and accumulate anthocyanins at various levels. Pebrianti et al. (2015), anthocyanins are bioactive components of flavonoids that can produce red, purple, blue colors in flowers, leaves, tubers, fruits, and vegetables. According to Mori et al. (2010); different anthocyanin profiles influence Oertel et al. (2017); and Bonar et al. (2018), the difference in the color of the red and purple tissues. Red skin color is associated with the accumulation of pelanin and peonanin, whereas the purple potato, tubers are enriched in malvanin, an accumulated anthocyanin cumaroylated malvidin. The PKHT-2019-011 genotype has dark purple tuber rind color. Besides, Intan has brown tuber rind color and the rest has yellow rind color. The color of the flesh of each genotype generally has a light yellow color (Figure 4). The Medians has white and PKHT-2019-011 has dark purple (Table 9).

\section{Production aspects}

Potato plants are ready for harvest when $80-85 \%$ of the population has shown yellowing of leaves and stems. The part of the potato plant that is harvested is the tuber part (Samadi 2007). According to Wohleb et al. (2014), potato tubers act as carbohydrate and nutrient storage organs that help plant growth as well as organs for vegetative propagation. The weight per unit of tubers obtained varies widely, ranging from 22.14-101.16 g. The PKHT-2019-015 genotype had the highest unit weight of tubers and was not significantly different from the comparison varieties of Intan (Table 10).

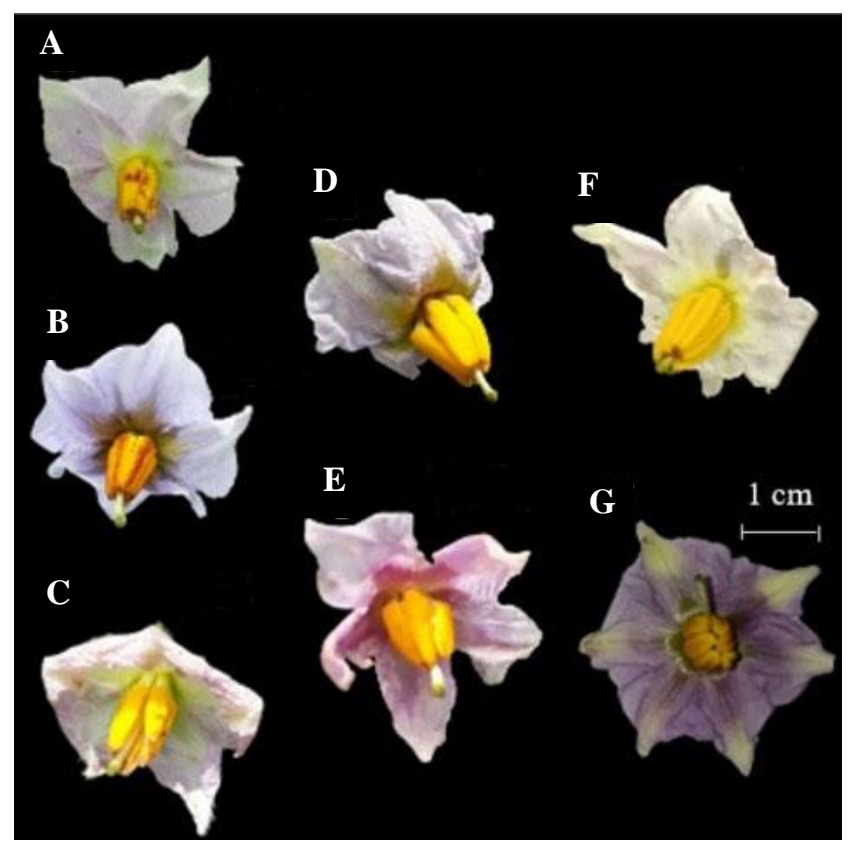

Figure 2. Potato flowers appearance of the IPB potato genotype. Description: a. PKHT-2019-010; b. PKHT-2019-011; c. PKHT2019-013; d. PKHT-2019-015; e. PKHT-2019-016; f. PKHT2019-017; g. Medians. PKHT-2019-012, PKHT-2019-014 and Intan are the non-flowering potato plants

Table 10. Weight of tuber and classification of commercial tuber grade based on SNI-01-3175-1992 for each IPB potato genotype

\begin{tabular}{|c|c|c|c|c|c|c|c|c|}
\hline \multirow{2}{*}{ Genotype } & \multirow{2}{*}{$\begin{array}{c}\text { Weight per } \\
\text { unit (g) }\end{array}$} & \multirow{2}{*}{$\begin{array}{c}\text { Number of tubers } \\
\text { per plant }\end{array}$} & \multirow{2}{*}{$\begin{array}{l}\text { Weight per } \\
\text { plant (g) }\end{array}$} & \multirow{2}{*}{$\begin{array}{l}\text { Weight per } \\
\text { ha }\left(\text { ton ha } h^{-1}\right)\end{array}$} & \multicolumn{4}{|c|}{ Commercial tubers grade classification (\%) } \\
\hline & & & & & Very large & Big & Medium & Small \\
\hline PKHT-2019-010 & $33.42 \mathrm{bc}$ & $15.1 \mathrm{a}$ & $471.35 \mathrm{~b}$ & $33.67 \mathrm{~b}$ & 0.00 & $10.65 \mathrm{~cd}$ & $32.46 \mathrm{ab}$ & $56.89 \mathrm{~b}$ \\
\hline PKHT-2019-011 & $37.81 b c$ & $3.6 \mathrm{~d}$ & $170.24 f g$ & $12.16 \mathrm{fg}$ & 0.00 & $4.71 \mathrm{~cd}$ & $43.55 \mathrm{a}$ & $51.74 \mathrm{bc}$ \\
\hline PKHT-2019-012 & $40.22 b c$ & $7.1 \mathrm{bc}$ & 297.37def & $21.24 \mathrm{def}$ & 0.00 & $2.84 \mathrm{~cd}$ & $44.94 \mathrm{a}$ & $52.22 \mathrm{bc}$ \\
\hline PKHT-2019-013 & $22.14 \mathrm{c}$ & $5.9 \mathrm{bcd}$ & $147.79 \mathrm{~g}$ & $10.56 \mathrm{~g}$ & 0.00 & 0.00 & $11.19 \mathrm{~cd}$ & $88.81 \mathrm{a}$ \\
\hline PKHT-2019-014 & $23.58 \mathrm{c}$ & $6.0 \mathrm{bcd}$ & $129.52 \mathrm{~g}$ & $9.25 \mathrm{~g}$ & 0.00 & 0.00 & 0.00 & $100.00 \mathrm{a}$ \\
\hline PKHT-2019-015 & $101.16 \mathrm{a}$ & $8.1 \mathrm{~b}$ & $719.74 \mathrm{a}$ & $51.41 \mathrm{a}$ & 4.25 & $63.91 \mathrm{a}$ & $22.14 b c$ & $9.70 \mathrm{~d}$ \\
\hline PKHT-2019-016 & $39.64 b c$ & $5.8 \mathrm{bcd}$ & $197.43 \mathrm{efg}$ & 14.10efg & 0.00 & $16.55 \mathrm{bcd}$ & $37.84 \mathrm{ab}$ & $45.61 \mathrm{bc}$ \\
\hline PKHT-2019-017 & $50.72 b$ & $13.7 \mathrm{a}$ & $450.81 b c$ & $32.20 b c$ & 0.00 & $20.64 b c$ & $41.12 \mathrm{ab}$ & $38.24 b c$ \\
\hline Intan & $87.86 \mathrm{a}$ & $3.8 \mathrm{~cd}$ & $310.14 \mathrm{de}$ & $22.15 \mathrm{de}$ & 0.00 & $55.69 a$ & $33.01 \mathrm{ab}$ & $11.30 \mathrm{~d}$ \\
\hline Medians & $48.63 b$ & $7.6 \mathrm{~b}$ & $341.24 \mathrm{~cd}$ & $24.37 \mathrm{~cd}$ & 0.00 & $30.54 \mathrm{~b}$ & $37.68 \mathrm{ab}$ & $31.78 \mathrm{c}$ \\
\hline
\end{tabular}

Note: The numbers followed by the same letter in the same column show the results are not significantly different in the Duncan test at the level of $\alpha=5 \%$. 
The weight of tubers is more important than the number of tubers per plant in potato cultivation for consumption, inversely proportional to those intended for seeds (Kusmana 2012). The number of tubers per plant, based on the data obtained, ranges from 3.6-15.1. The highest number of tubers is PKHT-2019-010 and PKHT-2019-017. According to Kusandriani (2014), the potato genotype with the character of the highest number of tubers can benefit farmers in procuring seeds for further planting. The number of tubers produced is large, it will not affect the weight of the tubers if the tubers are small. According to Wulandari et al. (2014), this can occur because the stolons that are formed on the stems are many, so there is competition in the tuber formation process.

Based on the research results, the distribution of tuber weight per plant of the tested potato plants ranged from 129.52-719.74 grams. PKHT-2019-015 genotype had the highest tuber weight per plant compared to other genotypes and control varieties. PKHT-2019-014 has the lowest weight per plant, not statistically different from PKHT2019-013, PKHT-2019-011, and PKHT-2019-016.

The high intensity of rainfall and the attack of plant pests affected the quantity and quality of potato tubers. The low weight per plant of PKHT-2019-014 is due to the low percentage of growth, which is thought to be rotten seeds due to infection with bacterial wilt disease. Gold et al. (2020) reported that the new potato cultivars are a challenge due to phenotypic variations and affect for potential risk of high yields and quality loss. The PKHT2019-013 genotype has a low weight per plant because the $G$. orientalis attack many tubers, and the resulting tuber weight is relatively small. PKHT-2019-011 has a low weight per plant due to bacterial wilt attack that attacks plants during vegetative growth, so harvesting is carried out earlier.

Based on the data tested (Table 10), the PKHT-2019015 genotype had the highest weight per ha compared to other genotypes and comparison varieties. The weight per ha of potato genotype PKHT-2019-015 reached 51.41 ton $\mathrm{ha}^{-1}$. The PKHT-2019-010 genotype has a weight per ha reaching 33.67 ton $\mathrm{ha}^{-1}$, not a statistically significant difference from PKHT-2019-017 reaching 32.20 tonnes ha 1. The potato genotypes PKHT-2019-015, PKHT-2019010, and PKHT-2019-017 had high productivity compared to the comparison varieties of Intan and Medians. PKHT2019-012 has a productivity that is not significantly different from Intan.

The tuber width is the diameter of the tuber measured on the y-axis. The tuber length of each genotype varied from 3.64-6.66 cm. Intan has the highest tuber length, not significantly different from PKHT-2019-012 and PKHT2019-015. The tuber width of each genotype ranges from 2.65-4.82 cm. PKHT-2019-015 genotype had the highest tuber width compared to other genotypes and control varieties. The PKHT-2019-011 genotype had the largest number of sprouts and was not significantly different from PKHT-2019-015. The average number of sprouts is ranged from 2.7 to 8.0 (Table 9). The number of sprouts that is too much is not very attractive to be used as consumption potatoes because of their physical appearance.

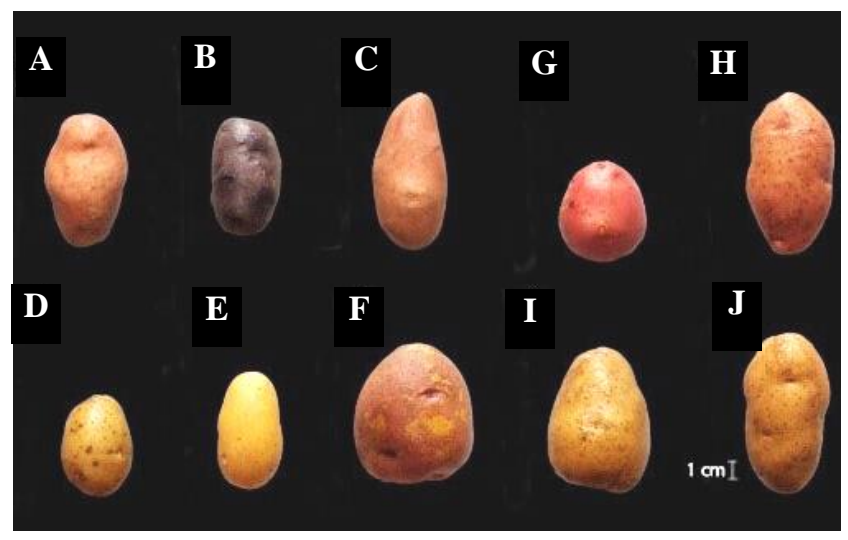

Figure 3. Tuber appearance and tuber rind color of the IPB potato genotype. Description: a. PKHT-2019-010; b. PKHT-2019-011; c. PKHT-2019-012; d. PKHT-2019-013; e. PKHT-2019-014; f. PKHT-2019-015; g. PKHT-2019-016; h. PKHT-2019-017; i. Medians; j. Intan.

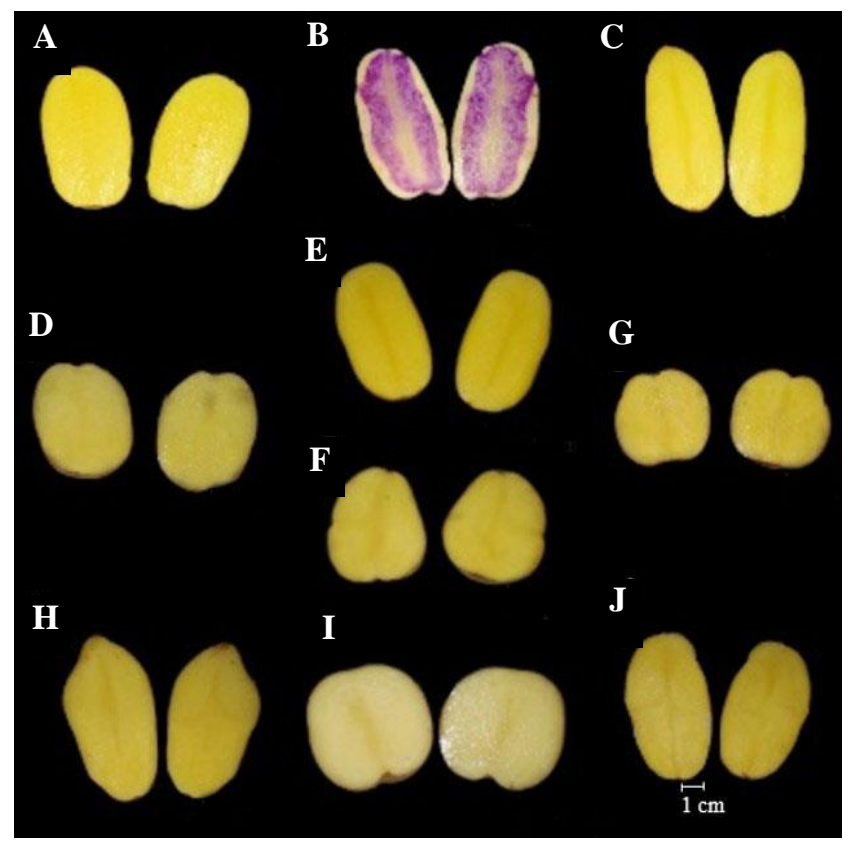

Figure 4. Tuber flesh color of the IPB potato genotype. Description: a. PKHT-2019-010; b. PKHT-2019-011; c. PKHT2019-012; d. PKHT-2019-013; e. PKHT-2019-014; f. PKHT2019-015; g. PKHT-2019-016; h. PKHT-2019-017; i. Medians; j. Intan.

Based on UPOV (2004), the tuber shape character is divided into six types, namely round, short round, oval, long oval, long, very long. The shape of the tubers produced varies greatly with each potato genotype. The shape of the potato tubers is obtained based on the ratio of the length and width of the tubers, then multiplied by 100 with the dominant tuber size and shape. The PKHT-2019010, PKHT-2019-014, and PKHT-2019-017 genotypes have a long tuber shape, while PKHT-2019-012 has a very long tuber shape. The short oval tuber shape is owned by PKHT-2019-013, PKHT-2019-015, PKHT-2019-016, and Medians. 


\section{Grading potato tubers}

According to the National Standardization Agency for Indonesia, it has determined the standard for grouping in SNI 01-3175-1992. The grouping is divided into very large $(<301 \mathrm{~g})$, large (101-300 g), medium (51-100 g), and small $(<50 \mathrm{~g})$ based on unit tuber weight (BSN 1992). Based on the data, the PKHT-2019-015 genotype has the best grading results compared to other genotypes (Table 10). The very large was $4.25 \%$, the large grade was $63.91 \%$, the medium grade was $22.14 \%$, and the small grade was $9.70 \%$.

According to Fatimah (2011), tubers size that meets market demand or suitable for sale are tubers with weight $>50 \mathrm{~g}$. If used for seeds, G3 planting material with $21-40 \mathrm{~g}$ and can increase yields by $29.43 \%$ (Wulandari et al. 2014). The small grade in this study dominated the number of tuber weights; presumably, the environmental conditions were less than optimal. High rainfall during the study when the plants were 14-63 DAP (when they were actively forming tubers) could inhibit the formation of tubers and the resulting tubers were not optimal.

We conclude that the tested potato genotypes had a variety of leaves, stems, flowers, and tubers. The results showed that the PKHT-2019-015, PKHT-2019-010, and PKHT-2019-017 genotypes had the highest productivity, while PKHT-2019-012 was equivalent to control varieties. Further testing is needed on pest and disease resistance of several IPB potato genotypes, especially PKHT-2019-011 and PKHT-2019-014. Research land conditions with high rainfall intensity resulted in increased pests and diseases. Genotypes that have a higher yield or the same as the comparison varieties can be developed and become alternatives as new varieties.

\section{ACKNOWLEDGEMENTS}

The authors thank PKHT-Center for Horticulture Tropical Studies of LPPM IPB, Bogor, Indonesia 2020 who has financially supported this research

\section{REFERENCES}

Asgar A, Rahayu ST, Kusmana, Sofiari E. 2011. Quality testing of severa potato clones for potato chips. J Hort 21: 51-59. [Indonesian]

Barunawati N, Zakariyah NF. 2016. Increasing production of potato (Solanum tuberosum) L. var. Nadia at medium land through application of compost goat manure potassium. Plantrop J Agric Sci 1: $12-17$.

BMKG-Meteorology, Climatology, and Geophysical Agency. 2020 Rainfall and Humidity Data for January-April 2020 in Cikajang Subdistrict, Garut, West Java. BMKG West Bandung, West Java. [Indonesian]

Bonar N, Liney M, Zhang R, Austin C, Dessoly J, Davidson D, Stephens J, McDougall G, Taylor M, Bryan GJ, Hornyik C. 2018. Potato miR828 is associated with purple tuber skin and flesh color. Front Plant Sci 9: 1-16. DOI: 10.3389/fpls.2018.01742

BPS-Central Bureau of Statistics. 2020. Dynamic Table of Horticultural Subjects 2020. www.bps.go.id [Indonesian]

BPTP-Agricultural Technology Research Center. 2015. Technical Instructions for Potato Cultivation. BPTP, Bandung. [Indonesian]

BSN-The National Standardization Body of Indonesia. 1992. Fresh Potatoes: SNI 01-3175-1992. BSN, Jakarta. [Indonesian]
Dhar MK, Sharma R, Koul A, Kaul S. 2015. Development of fruit color in Solanaceae: a story of two biosynthetic pathways. Briefings Funct Genom 14: 199-212. DOI: 10.1093/bfgp/elu018.

Directorate of Horticulture, Ministry of Agriculture. 2015. Technical Propagation and Certification of Potato Seeds (Solanum tuberosum L.). Ministry of Agriculture Indonesia, Jakarta. [Indonesian]

Duncan D. 1955. Multiple Range and Multiple F Tests. Biometrics 11: 142. DOI: $10.2307 / 3001478$.

Ebrahim S, Mohammed H, Ayalew T. 2018. Effects of seed tuber size on growth and yield performance of potato varieties under field conditions. Afr J Agric Res 13: 2077-2086. DOI: 10.5897/AJAR2018.13405.

Fatimah SN. 2011. Marketing Analysis of Potato (Solanum tuberosum L.) in Wonosobo District. [Thesis]. Universitas Sebelas Maret, Surakarta. [Indonesian]

Gold KM, Townsend PA, Herrmann I, Gevens AJ. 2020. Investigating potato late blight physiological differences across potato cultivars with spectroscopy and machine learning. Plant Sci 295: 1-12. DOI: 10.1016/j.plantsci.2019.110316

Hasibuan S, Tantawi AR, Gusmeizal. 2017. Robustness test of several potato clon in the medium plains. J Agric Vet Sci 10: 61-65.

Haqq MH. 2020. The Yield Test and Characterization of Some Potato Genotypes (Solanum tuberosum L.) of IPB Collection in Garut District, West Java. [Thesis]. Institut Pertanian Bogor, Bogor. [Indonesian]

Hidayat YS. 2014. Morphological Characterization of Some Genotypes of Potato Cultivated in Indonesia. [Thesis]. Institut Pertanian Bogor, Bogor. [Indonesian]

Hidayat YS, Efendi D, Sulassih. 2018. Morphological characterization of some genotypes of potato (Solanum tuberosum L.) cultivated in Indonesia. Comm Hortic J 2: 28-34. DOI: 10.29244/chj.2.1.28-34 [Indonesian]

Indawati N. 2012. Complete Guidelines for Growing Potatoes. Pustaka Baru Press, Yogyakarta. [Indonesian]

KEMENTAN-Ministry of Agriculture. 2017. Agricultural Statistics 2017. www.pertanian.go.id [Indonesian]

Kusandriani Y. 2014. Tuber yield trial and quality of eight potato genotypes for national potato chipping industry use local raw material. J Hort Indonesia 24: 283- 288. [Indonesian]

Kusmana. 2012. Selection of several potato clones (Solanum tuberosum L.) derived from crosses for high yielding on the highland of Ciwidey. Bul Plasma Nutfah 18: 45-53. DOI: 10.21082/blpn.v18n2.2012.p45-53. [Indonesian]

Kuswanto. 2008. The Role of Plant Breeding to Provide Healthy Vegetables Free Pesticides; Professor Inauguration Oration. Universitas Brawijaya, Malang, 23 December 2008. [Indonesian]

Laisina JKJ, Maharijaya A, Sobir, Purwito A. 2021. Drought adaptive prediction in potato (Solanum tuberosum) using in vitro and in vivo approaches. Biodiversitas 22 (2): 537-545. DOI: 10.13057/biodiv/d220204

Maharijaya A. 2007. In Vitro Selection of Clones Derived from Crossing between cv Atlantic and cv Granola to Obtain Putative Superior Potato Cultivars. [Thesis]. Institut Pertanian Bogor, Bogor. [Indonesian]

Maharijaya A, Mahmud M, Purwito A. 2008. In vitro test of potato clones derived from crossing between cv Atlantic and Granola for their tolerance to bacterial wilt (Ralstonia solanacearum) and soft rot (Erwinia carotovora). J Agron Indonesia 36: 133-138. [Indonesian]

Maharijaya A, Vosman B. 2015. Managing the Colorado potato beetle; the need for resistance breeding. Euphytica 204: 487-501. DOI: 10.1007/s10681-015-1467-3.

Maharijaya A, Salma LN, Amarilis S. 2020. Yield and tuber quality potato (Solanum tuberosum L.) of IPB collection for potato chips industries. J Agron Indonesia 48(3): 275-282. DOI: 10.24831/jai.v48i3.32979. [Indonesian]

Mori M, Hayashi K, Ohara-Takada A, Watanuki H, Katahira R, Ono H, Terahara N. 2010. Anthocyanins from skins and fleshes of potato varieties. Food Sci Technol Res 16: 115-22. DOI: 10.3136/fstr.16.115

Oertel A, Matros A, Hartmann, A, Arapitsas P, Dehmer KJ, Martens S, Mock HP. 2017. Metabolite profiling of red and blue potatoes revealed cultivar and tissue-specific patterns for anthocyanins and other polyphenols. Planta 246: 281-297. DOI: 10.1007/s00425-0172718-4.

Pebrianti C, Ainurrasyid RB, Purnamaningsih SL. 2015. Test anthocyanin content and yields of six varieties of red spinach (Alternanthera amoena Voss) in the rainy season. J Protan 3: 27-33. [Indonesian] 
Plantenga FDM, Bergonzi S, Abelenda JA, Bachem CWB, Visser RGF, Heuvelink E, Marcells LFM. 2019. The tuberization signal StSP6A represses flower bud development in potato. J Exp Bot 70: 937-948. DOI: $10.1093 / \mathrm{jxb} / \mathrm{ery} 420$.

Purwito A, Wattimena GA, Syukur M, Sobir, Nuryana FI, Harti H, Maharijaya A. 2017. Evaluation of potato clones for their adaption to medium altitude conditions in the tropics. Euphytica 213: 237. DOI 10.1007/s10681-017-2022-1.

PUSDATIN-Agricultural Data Center and Information Systems. 2018. Import of agricultural commodities based on HS code. www.database.pertanian.go.id [Indonesian]

Samadi B. 2007. Potatoes Farming. Kanisius, Yogyakarta. [Indonesian]

Saputro AW, Rianto H, Suprapto A. 2019. The yield of the potato (Solanum tuberosum L.) variety Granola L. (G1) at various concentrations of Trichoderma sp. and growing media. Vigor 4: 1-4. [Indonesian]

Sastrahidayat IR. 2011. Potato Crop and Pest Control. Universitas Brawijaya Press, Malang. [Indonesian]

Thomas-Sharma S, Abdurrahman A, Ali S, Andrade-Piedra L, Bao S, Charkowski AO, Crook, D. Kadian M, Kromann P, Struik PC, Torrance L, Garrett KA, Forbes GA. 2016. Seed degeneration in potato: the need for an integrated seed health strategy to mitigate the problem in developing countries. Plant Pathol 65: 3-16. DOI: 10.1111/ppa.12439

Upadhya MD, Takur KC, Juneja A, Kadian MS. 1984. True potato seed production: flowering, quality, and economics. Innovative methods for propagation potato. CIP, Lima.

UPOV-International Union for the Protection of New Varieties of Plants. 2004. Guidelines for the Conduct of Tests for Distinctness, Uniformity, and Stability of Potato (Solanum tuberosum L.). UPOV International. Geneva.

Wattimena GA. 2000. Development of Quality Potato Propagules and Superior Potato Varieties to Support Increased Potato Production in Indonesia; Permanent Professor Scientific Oration. Institut Pertanian Bogor, Bogor, 2 September 2000. [Indonesian]

Wohleb CH, Knowles NR, Pavek MJ. 2014. Plant growth and development. In: Navarre R, Pavek M (eds) The Potato: Botany, Production, and Uses. CPI Group Ltd, Croydon, CRO 4YY. London.

Wulandari AN, Heddy S, Suryanto A. 2014. The use of seed tuber weight to increase yield of potato plants (Solanum tuberosum L.) G3 dan G4 Granola Variety. J Produksi Tanaman 2: 65-72. [Indonesian]

Zulkarnain DH, Maharijaya A, Syukur M. 2017. Yield trials of IPB Potato (Solanum tuberosum L.) promising lines in Garut District, West Java. Comm Hortic J 1: 42-48. DOI: 10.29244/chj.1.1.42-48. [Indonesian] 